\title{
Stem cell factor/c-Kit signalling in normal and androgenetic alopecia hair follicles
}

\author{
Valerie A Randall, Tracey J Jenner, Nigel A Hibberts, Isabel O De Oliveira and Tayyebeh Vafaee \\ Division of Biomedical Sciences, School of Life Sciences, University of Bradford, Bradford BD7 1DP, UK \\ (Correspondence should be addressed to V A Randall; Email: v.a.randall@bradford.ac.uk)
}

\begin{abstract}
Androgens stimulate many hair follicles to alter hair colour and size via the hair growth cycle; in androgenetic alopecia tiny, pale hairs gradually replace large, pigmented ones. Since stem cell factor (SCF) is important in embryonic melanocyte migration and maintaining adult rodent pigmentation, we investigated SCF/c-Kit signalling in human hair follicles to determine whether this was altered in androgenetic alopecia. Quantitative immunohistochemistry detected three melanocyte-lineage markers and c-Kit in four focus areas: the epidermis, infundibulum, hair bulb (where pigment is formed) and mid-follicle outer root sheath (ORS). Colocalisation confirmed melanocyte c-Kit expression; cultured follicular melanocytes also exhibited c-Kit. Few ORS cells expressed differentiated melanocyte markers or c-Kit, but NKI/beteb antibody, which also recognises early melanocyte-lineage antigens, identified fourfold more cells, confirmed by colocalisation. Occasional similar bulbar cells were seen. Melanocyte distribution,
\end{abstract}

concentration and c-Kit expression were unaltered in balding follicles. Androgenetic alopecia cultured dermal papilla cells secreted less SCF, measured by ELISA, than normal cells. This identifies three types of melanocytelineage cells in human follicles. The c-Kit expression by dendritic, pigmenting, bulbar melanocytes and rounded, differentiated, non-pigmenting ORS melanocytes implicate SCF in maintaining pigmentation and migration into regenerating hair bulbs. Less differentiated, c-Kit-independent cells in the mid-follicle ORS stem cell niche and occasionally in the bulb, presumably a local reserve for long scalp hair growth, implicate other factors in activating stem cells. Androgens appear to reduce alopecia hair colour by inhibiting dermal papilla SCF production, impeding bulbar melanocyte pigmentation. These results may facilitate new treatments for hair colour changes in hirsutism, alopecia or greying.

Journal of Endocrinology (2008) 197, 11-23

\section{Introduction}

Hair colour is often very important and may need to alter to allow appropriate changes, e.g. signalling of sexual maturity (Jansen \& van Baalen 2006) or seasonal camouflage (Flux 1970). In men, highly pigmented beard hair replaces the almost colourless, tiny vellus hairs on the child's face after puberty (Marshall \& Tanner 1970), while the older, mature male is frequently distinguished by the reverse process on the scalp causing androgenetic alopecia or male pattern baldness. Androgens are the main regulator of human hair follicles (reviewed in Randall (2007)) causing the changes signalling adulthood and, paradoxically, also androgenetic alopecia (Hamilton 1951, 1958). Darker lion manes also correlate with higher testosterone levels (West \& Packer 2002) and testosterone increases pigmentation in Mallard feathers (Haase et al. 1995) and deer hair (Bubenik \& Bubenik 1985).

Hair follicles can change the size and colour of the hairs they produce via their unique ability to regenerate themselves during the regular cycles of growth (anagen), regression (catagen) and rest (telogen) during which the hair is shed and replaced (Kligman 1959). The new hair may be identical in colour to the previous one, as frequently occurs on normal human scalp, or very different like the Scottish hare's brown summer coat (Flux 1970). Hair colour depends on the amount and type of pigment present in the hair shaft, including the balance of brown/black eumelanin and red/yellow phaeomelanin. Melanocytes located in the epithelial cell matrix of the anagen hair bulb, around the top of the dermal papilla, synthesise melanins in specialised organelles, melanosomes, exporting them to adjacent keratinocytes in the bulb (Chase 1958; reviewed in Castanet \& Ortonne (2000), Slominski et al. 2004, Lin \& Fisher 2007). Unlike the epidermis, the follicular melanin synthesis is cyclical, closely coupled to the anagen hair manufacture (Burnett et al. 1969, Commo \& Bernard 2000, Slominski et al. 2004, Sharov et al. 2005).

Although hormones are known to coordinate with seasonal and age/sex-related changes in the hair follicles (Randall 2007), our understanding of how follicle pigmentation is controlled is limited. Androgens are believed to act on follicles predominantly via the mesenchyme-derived dermal papilla, 
situated within the hair bulb at the follicle base (Randall 2007); this regulates many aspects of follicular activity and determines the hair type produced (Reynolds \& Jahoda 2004, Waters et al. 2007). In the current mechanism, androgens alter dermal papilla production of regulatory paracrine factors, e.g. growth factors and/or extracellular matrix components, which influence the follicular target cells (Randall et al. 1991, Randall 1994, 2007). Follicular melanocytes would be the targets in hair colour alterations.

Local factors can influence not only epidermal melanocytes, particularly the melanocortins and adrenocorticotrophic hormone (ACTH), but also $\beta$-endorphin, endothelin, prostaglandins and catecholamines etc (reviewed in Slominski et al. (2004), Lin \& Fisher 2007). Such factors regulating follicular melanocytes are not so well established, although pro-opiomelanocortin, ACTH and $\alpha$-melanocyte-stimulating hormone $(\alpha-\mathrm{MSH})$ seem to have local roles, particularly in balancing eumelanin and phaeomelanin proportions (reviewed in Slominski et al. (2004), Tobin \& Kauser 2005, Costin \& Hearing 2007, Rousseau et al. 2007). In addition, the cytokine, stem cell factor (also called SCF, mast cell growth factor, steel factor or c-Kit ligand) and its cell surface receptor, c-Kit, play important roles in both epidermal and hair pigmentation (Williams et al. 1992). Both are essential to enable melanocyte-lineage cell migration from the neural crest into developing murine hair follicles (Zsebo et al. 1990, Geissler et al. 1988, Jordan \& Jackson 2000) and people with the white forelock of piebaldism exhibit mutations in the $c$-Kit gene (Fleischman et al. 1991, Spritz et al. 1992). The SCF/ c-Kit system is also involved in post-natal rodent hair cycles; c-Kit antibodies inhibit murine hair pigmentation (Nishikawa et al. 1991), promote apoptosis of follicular melanocytes (Okura et al. 1995) and prevent regeneration of the follicle bulb pigment units in the next anagen (Botchkareva et al. 2001). Similarly, overexpression of epidermal SCF causes epidermal hyperpigmentation in mice and atypical melanocyte distribution (Kunisada et al. 1998a,b). Since melanocytes synthesising follicle pigment are physically close to the dermal papilla in the bulb, we hypothesised that it was a local source of SCF; this is supported by secretion of SCF by cultured dermal papilla cells (Hibberts et al. 1996, Lu et al. 2006).

Most research focuses on laboratory rodent follicles, but these have significant differences to human follicles: no colour changes after puberty, no major responses to androgens, much smaller size, anagen involving weeks not the years of scalp growth and no epidermal melanocytes. We aimed to further investigate SCF/c-Kit signalling in normal human anagen hair follicles and to compare it in androgenetic alopecia to see if the androgen-promoted reduced pigmentation in balding involved changes in the SCF/c-Kit system. Two approaches were employed: follicular melanocyte-lineage cell distribution and expression of the SCF receptor, c-Kit were compared in normal and androgenetic alopecia hair follicles using immunohistochemistry, and the ability of cultured dermal papilla cells derived from normal and balding scalp to produce SCF measured. Initially, the expression of antigens associated with stages of melanocyte-lineage cell development and c-Kit were compared in frozen sections to determine whether this varied with follicular location or with the follicle's response to androgens in vivo, focusing particularly on the site of pigment synthesis, the hair bulb, the melanocyte stem cell niche in the mid-follicle outer root sheath (ORS), i.e. the lower part of the permanent follicle, ORS, below the sebaceous ductl (Staricco 1959, Sugiyama \& Kukita 1976, Horikawa et al. 1996, Narisawa et al. 1997, Commo \& Bernard 2000, Botchkareva et al. 2001, Nishimura et al. 2002, 2005, Steingrimsson et al. 2005), the infundibulum and epidermis. Three antibodies to melanocyte-lineage cells were used to discriminate between differentiation stages; NKI/ beteb recognises all melanocyte-lineage cells including very immature ones, as it binds 7 and $100 \mathrm{kDa}$ antigens in premelanosome-like structures, premelanosomes and melanosomes (Hayashibe et al. 1986), while HMB-45 and Mel-2 only recognise mature melanocytes binding to $10 \mathrm{kDa}$ melanosome-associated and cell surface protein antigens respectively (Kapur et al. 1992); Mel-2 was selected for direct comparison with c-Kit, a membrane receptor. Antibodies to tyrosinase-related protein (TRP)-2 used to locate immature melanocytes in rodents (Botchkareva et al. 2001) were not employed, as these did not stain human follicular melanocytes here or elsewhere (Commo et al. 2004a). The number of cells stained with each antibody in every region was quantified in each individual studied; using two antibodies to different mature melanocyte antigens on parallel sections of each sample provided an internal control to check quantitation reliability. To confirm, the human follicle melanocyte expression of c-Kit colocalisation studies of c-Kit and melanocyte-lineage antigens and immunocytochemistry of primary lines of cultured epidermal and follicular melanocytes were also carried out. Finally, primary lines of dermal papilla cells were derived from normal scalp follicles and intermediate androgenetic alopecia follicles and their SCF production measured by ELISA after culture in the presence, and absence, of testosterone. This enabled the comparison of any in vivo or in vitro effects of androgens. Since hair colour normally remains unchanged within a cycle even over the years required for long hair, in vitro effects were not anticipated.

\section{Materials and Methods}

\section{Skin samples}

Scalp skin by-products of routine surgical procedures were collected from apparently healthy Caucasian adults. This included: five women and three men, aged 38-52 for the main immunohistochemical study and one man and four women aged 34-48 for melanocyte culture. Non-balding (occipital) scalp of 12 men, some with male pattern baldness, aged 38-59, were used for the colocalisation immunohistological studies and for non-balding dermal papilla cell 
culture. Balding vertex scalp samples were obtained from 13 men with androgenetic alopecia aged 24-46 years for immunohistochemical analysis and dermal papilla cell culture. Foreskin samples were obtained similarly from four males aged 2-12 years. Declaration of Helsinki protocols were followed and appropriate patient consent and local Ethical Committee approval obtained. There was no evidence of hair thinning or loss of pigmentation in the non-balding samples, but balding skin contained much smaller hair follicles producing finer, less pigmented hairs. Skin samples were collected in sterile culture medium or PBS and transported to the laboratory at $4{ }^{\circ} \mathrm{C}$ taking up to $6 \mathrm{~h}$ for normal skin, and up to $24 \mathrm{~h}$ for androgenetic alopecia samples, before embedding in OCT and freezing at $-80^{\circ} \mathrm{C}$ or processing for cell culture.

\section{Immunohistochemistry}

Vertical frozen sections (5-8 $\mu \mathrm{m}$ thick) were cut using a Leica cryostat (CM 1800) and collected on poly-L-lysine-coated slides to increase adherence (Marzia et al. 1975). Special care was needed during sectioning to orientate the specimen to obtain longitudinal sections of hair follicles. Poly-L-lysine (BDH Chemicals Ltd, Poole, Dorset, UK) diluted 1:10 with double distilled water was applied to very clean, dry slides previously soaked in methanol. After $5 \mathrm{~min}$, the excess was removed and the slides were left to air dry. Sections were fixed in acetone at $4{ }^{\circ} \mathrm{C}$ for $10 \mathrm{~min}$ and air dried for $3-24 \mathrm{~h}$. All staining took place in a moistened chamber at room temperature.

Endogenous peroxidase activity was blocked by adding five drops of 3\% hydrogen peroxide:methanol (1:4) solution for 20 min. After rinsing with PBS, followed by immersion in further PBS for $10 \mathrm{~min}$, non-specific binding sites were blocked by incubation with mouse serum (1:100) (Dako, Buckinghamshire, UK) for $20 \mathrm{~min}$, followed by 1-h incubation with various primary mouse anti-human monoclonal antibodies. After investigating various dilutions and incubation times, antibodies were used at the following dilutions: NKI/beteb 1:10 (Monosan, Uden, The Netherlands), HMB-45 1:10 (Dako), Mel-2 1:20 (Serotec, Kidlington, Oxford, UK) and c-Kit 1:10 (Serotec). Positive controls of parallel incubations of foreskin sections and two negative controls of scalp skin with either PBS or an antibody (1:20) to Aspergillus niger glucose oxidase, a protein absent from mammalian tissues (Dako), were carried out with each series. After washing with PBS for $10 \mathrm{~min}$ (also repeated after each of the next stages), sections were incubated with a secondary antibody, biotinylated anti-rabbit and anti-mouse immunoglobulins, (Dako) for $20 \mathrm{~min}$. Excess liquid was removed after washing by blotting carefully with tissue and four to six drops of horseradish peroxidase-streptavidin complex (Dako) per section were incubated for $20 \mathrm{~min}$. Similar amounts of chromagen 3-amino-5-ethylcarbazole (AEC; Dako) followed the next wash for about $20 \mathrm{~min}$; red colour appearance was monitored microscopically. Final rinsing with PBS was followed by mounting using an aqueous mountant, Glycergel (Dako).
Analysis of quantitative results All sections were examined on a Leitz Ortolux light microscope using wide field Periplan NG/GF eyepieces and the number of stained cells per field were counted in a $0.45 \mathrm{~mm}$ field under $400 \times$ magnification; care was taken to check that actual cells were counted by altering the focal depth. The numbers of positive cells for each region were quantified from at least 5 , and up to 15, sections for each antibody for each of the eight nonbalding and eight balding individuals. These were averaged for each individual and then the mean \pm s.E.M. obtained for each antibody in each region. Initially, the normal and balding results were analysed separately and data were checked using the SPSS statistical package to determine if a Gaussian normal distribution would enable the use of parametric statistical analysis. Since there were three different factors, i.e. the donor, the site and the antibody, which could affect the numbers of stained cells, three-way ANOVA was carried out by testing donor against site and antibody. Since there was no effect of donor, the results from each site and each antibody were analysed by two-way ANOVA. Further, two-way ANOVAs were carried out to determine whether there were any differences for any antibodies at any site between normal and balding skin.

\section{Colocalisation studies}

Dual staining experiments were carried out using two primary antibodies and blue and red chromagens. Sections were incubated with 3\% BSA for $30 \mathrm{~min}$ followed by an avidin-biotin blocking kit (Vector Laboratories, Peterborough, UK) involving $15 \mathrm{~min}$ avidin, $1 \mathrm{~min}$ PBS and $15 \mathrm{~min}$ biotin to block non-specific staining. The same antibodies were used, as previously described, except that Mel-2 was replaced by Mel-5 that recognises a $75 \mathrm{kDa}$ glycoprotein (Bhawan 1997; Signet Laboratories, Dedham, MA, USA; 02026). The first primary antibody was incubated for $60 \mathrm{~min}$, followed by the biotinylated secondary antibody, horse antimouse IgG for $30 \mathrm{~min}$ and the $0 \cdot 2 \mathrm{ml}$ ABC-AP complex (Vector Laboratories) for $30 \mathrm{~min}$ with four drops of substrate Vector blue (Vector Laboratories); sections were washed carefully with PBS between steps. The second primary antibody was applied and all steps were repeated, but using vector red (Vector laboratories) as the second substrate.

\section{Antigen expression by cultured melanocytes}

Epidermal and hair follicular melanocytes were isolated from scalp skin using the method established by Tobin et al. (1995). Briefly, after $1 \mathrm{~h}$ in Eagle's minimum essential medium (EMEM; Gibco) containing penicillin $(100 \mathrm{IU} / \mathrm{ml})$ and streptomycin $(100 \mu \mathrm{g} / \mathrm{ml}$; both Sigma Chemical Co. $)$ to reduce infection risk, the epidermis and $\sim 1 \mathrm{~mm}$ of the upper dermis were removed, cut into $1 \mathrm{~cm}^{3}$ pieces and incubated in medium supplemented with $0 \cdot 5 \%$ collagenase type V (Sigma) and $5 \%$ fetal bovine serum (FBS; Globepharm, Surrey, UK) 
for $1-2 \mathrm{~h}$ at $37^{\circ} \mathrm{C}$ to separate the epidermis. Hair follicles were washed in PBS until microscopic examination confirmed removal of contaminating dermal tissue and then tissues were incubated with $0.05 \%$ trypsin with $0.53 \mathrm{mM}$ EDTA (Sigma) for $5-10 \mathrm{~min}$ at $37^{\circ} \mathrm{C}$ to produce single cell suspensions. The cells were cultured in $35 \mathrm{~mm}$ tissue culture dishes (Scientific Laboratory Supplies, Nottingham, UK) in the EMEM as described above, supplemented with 10\% FBS, $0 \cdot 2 \mu \mathrm{g} / \mathrm{ml}$ cholera toxin (Sigma), $50 \mathrm{nM} 12$-o-tetradecanoyl phorbol-13-acetate (TCS Biologicals, Buckinghamshire, UK) and keratinocyte serum-free medium (KSFM; TCS Biologicals; EMEM: KSFM, 2:1). Any contaminating fibroblasts were removed with geneticin treatment (TCS Biologicals; Halaban \& Alfano 1984) and keratinocytes by differential trypsinisation (Eisinger \& Marko 1982). Melanocyte cultures at passage 2 were maintained in medium without phorbol esters or cholera toxin for $48 \mathrm{~h}$ prior to immunocytochemistry. The cells $\left(1 \times 10^{3}\right)$ were seeded onto sterile 12-well tissue-culture treated $5 \mathrm{~mm}$ slides with removable lids for immunocytochemistry and incubated at $37^{\circ} \mathrm{C}$ overnight. The cells were fixed and stained as described for frozen sections above.

\section{Comparison of SCF production by normal and balding dermal papilla cells}

Culture of dermal papilla cells Skin samples were transported in E199 medium (Sigma) and transferred to fresh medium on arrival. Primary cultures of dermal papilla cells were established from small pieces of full depth scalp skin by the methods established for non-balding and balding dermal papilla cells described previously (Messenger 1984, Randall et al. 1996). Balding dermal papillae were isolated from the small intermediate follicles from large samples of balding scalp, rather than the tiny vellus follicles, because these are actually undergoing changes in response to androgens and also because of the extreme technical difficulties of isolating dermal papillae from miniature vellus follicles. Briefly, skin samples were microdissected in $100 \mathrm{~mm}$ sterile Petri dishes containing E199 medium, supplemented with glutamine $(2 \mathrm{mmol} / \mathrm{ml})$, penicillin $(100 \mathrm{IU} / \mathrm{ml})$, streptomycin $(100 \mu \mathrm{g} / \mathrm{ml})$ and amphotericin B $(2.5 \mu \mathrm{g} / \mathrm{ml})$; all supplements supplied by Gibco. Under a Wild dissecting microscope (Leitz), each follicle was removed separately and individually microdissected to isolate the dermal papilla; each individual papilla was then transferred to a $35 \mathrm{~mm}$ tissue culture-treated Petri dish (Bibby Sterilin, Stone, Staffordshire, UK) in the same medium supplemented with $20 \%$ serum. Depending on the sample size, three to eight dermal papillae were placed in one dish.

Primary cultures were left untouched in a humidified incubator at $37^{\circ} \mathrm{C}$ in $95 \%$ air: $5 \% \mathrm{CO}_{2}$ for 2 weeks to establish. They were then examined under phase contrast microscopy and the medium was changed weekly until sufficient cells had grown from the papillae (about 4-5 weeks), for subculture into a $25 \mathrm{~cm}^{2}$ tissue culture-treated flask (Bibby Sterilin) in the complete medium to establish primary cell lines; this was termed passage 1 . Thereafter, the cells were further subcultured into $25 \mathrm{~cm}^{2}$ flasks with a split ratio of 1:3 when almost confluent, generally after about 2 weeks. The cells were stored frozen in liquid nitrogen if not required immediately for experimental purposes.

Preparation of conditioned medium Primary cell lines of non-balding scalp $(n=6)$ and balding scalp $(n=5)$ dermal papilla cells at passage 4 were grown to confluence in $25 \mathrm{~cm}^{2}$ flasks in E199 medium supplemented with 10\% FCS. Each flask was washed with PBS $(5 \mathrm{ml} ; \times 4)$ to remove any remnants of serum and parallel flasks of each cell line were supplied with $5 \mathrm{ml}$ serum-free medium containing $10 \mathrm{nM}$ testosterone in $0.001 \%$ ethanol or the ethanol vehicle alone. After $15 \mathrm{~min}$, this 'conditioned' medium was removed from each cell line to determine whether there was any SCF in the system initially. This was replaced with further serum-free medium $(5 \mathrm{ml})$ with, or without, $10 \mathrm{nM}$ testosterone for $24 \mathrm{~h}$. The medium was centrifuged at $1000 \boldsymbol{g}$ to pellet cell debris, sterile filtered $(0 \cdot 2 \mu \mathrm{m})$ and stored at $-20{ }^{\circ} \mathrm{C}$.

Measurement of SCF The concentration of SCF was measured in serum-free medium and the various dermal papilla cell conditioned media using a sandwich ELISA kit, designed for cell culture medium and based on a monoclonal antibody capable of detecting natural human and recombinant SCF (R\&D Systems Europe, Abingdon, UK). A 10-point standard curve ranging from 0 to $100 \mathrm{pg} / \mathrm{ml}$ $\mathrm{SCF}$ in serum-free medium was measured in every assay. All points were assayed in duplicate according to the manufacturer's instructions. The absorbance of each well was measured at $450 \mathrm{nM}$ with wavelength correction set at $540 \mathrm{nM}$ on an ELISA plate reader zeroed against the assay buffer. The minimum detectable level of SCF was $3 \mathrm{pg} / \mathrm{ml}$ with a sensitivity of $3 \mathrm{pg} / \mathrm{ml}$; no significant cross-reactivity or interference between other cytokines has been detected. The SCF content was expressed as pg per $\mathrm{ml} / \mu \mathrm{g}$ of the medium protein content measured by the Bradford assay (Bradford 1976). Statistical analyses of the differences between SCF concentrations in the media were performed using the non-paired, one-tailed Student's $t$-test after confirmation of normal distribution.

\section{Results}

Immunohistochemical localisation of melanocyte antigens in scalp skin samples

Large amounts of readily visible brown pigment were seen in the hair cortex and in the epithelial matrix of the hair bulb above, and around, the upper portions of the dermal papilla of normal scalp follicles. In contrast, pigment was not obvious in the scalp epidermis. In balding samples less pigment was 
generally visible in the hair bulb and hair, but some was sometimes seen in the epidermis. Sectioning androgenetic alopecia follicles was even more difficult than normal ones due to their small size. Using a red chromagen enabled visualisation of staining amongst the melanin pigment in the hair bulb. All sections stained with the negative control antibody showed no positive staining, but appropriate positive intermittent, red, cellular staining was seen in the melanocytes of the basal layer of the epidermis in the foreskin sections with each antibody, confirming the specificity of the staining. All staining in scalp sections using single antibodies also showed red, intermittent, cellular staining. All results were normally distributed and the ANOVA tests showed that there was no discontinuity, i.e. variation within the donors at any site or with any antibody.

\section{Non-balding scalp skin}

$\mathrm{NKI} /$ beteb, an antibody that recognises melanocyte-lineage cells including very early development stages, stained cells in the basal layer of the epidermis (epidermis 10.80 $\pm 0 \cdot 30$; mean \pm s.E.M.; Fig. 1), but not in the upper layers. This pattern continued into the outer layer of the ORS of the follicle infundibulum (Fig. 2a) where the mean number of cells present per field was slightly, but insignificantly, higher $(14 \cdot 00 \pm 0 \cdot 50$, Fig. 1). Although there was some similar staining in the outer layer of the ORS of the mid-follicle, i.e. below the junction point of the sebaceous gland (Fig. 2b), the number of cells detected was much lower $(4 \cdot 00 \pm 0 \cdot 10)$ than in the epidermis $(P<0 \cdot 05)$, infundibulum $(P<0 \cdot 05)$ and hair bulb $(P<0 \cdot 001$; Fig. 1$)$. In the hair bulb, staining was predominantly seen in the matrix above, and around, the upper portion of the dermal papilla amongst the pigment (Fig. 2c). Staining was also observed on the outer edges of the matrix, mainly below the base of the dermal papilla, but no visible pigment was associated with these cells. More cells were detected in the hair bulb $(11.00 \pm 1: 10)$ than in the epidermis $(P<0 \cdot 001)$, but similar numbers were observed in the infundibulum (Fig. 1). No staining was observed in other parts of the skin.

Antibodies to the more differentiated melanocyte markers, HMB-45 and Mel-2, produced a similar distribution to $\mathrm{NKI} /$ beteb throughout the skin being confined to the basal layers of the epidermis, the ORS and the hair bulb (Fig. 2d-i). Both stained very similar numbers of cells in all sites (Fig. 1), detecting significantly fewer cells than NKI/beteb in all regions (HMB-45, Mel-2 epidermis $P<0.01,0.005$; infundibulum $P<0 \cdot 01,0 \cdot 01$; mid-follicle $P<0 \cdot 001,0 \cdot 001$; hair bulb $P<0 \cdot 01,0 \cdot 01)$. The proportions of HMB-45 or Mel-2 to NKI/beteb were $1: 1 \cdot 4-2 \cdot 2$, except in the midfollicle ORS where this increased dramatically to $1: 4$ $(P<0 \cdot 001)$. Staining with the antibody to $\mathrm{c}-\mathrm{Kit}$ was similarly distributed to the melanocyte-lineage antibodies (Fig. 2j-1), but additional staining of individual cells, probably mast cells, was also observed in the dermis. Stained cell numbers were very similar to those detected by HMB-45 and Mel-2 and

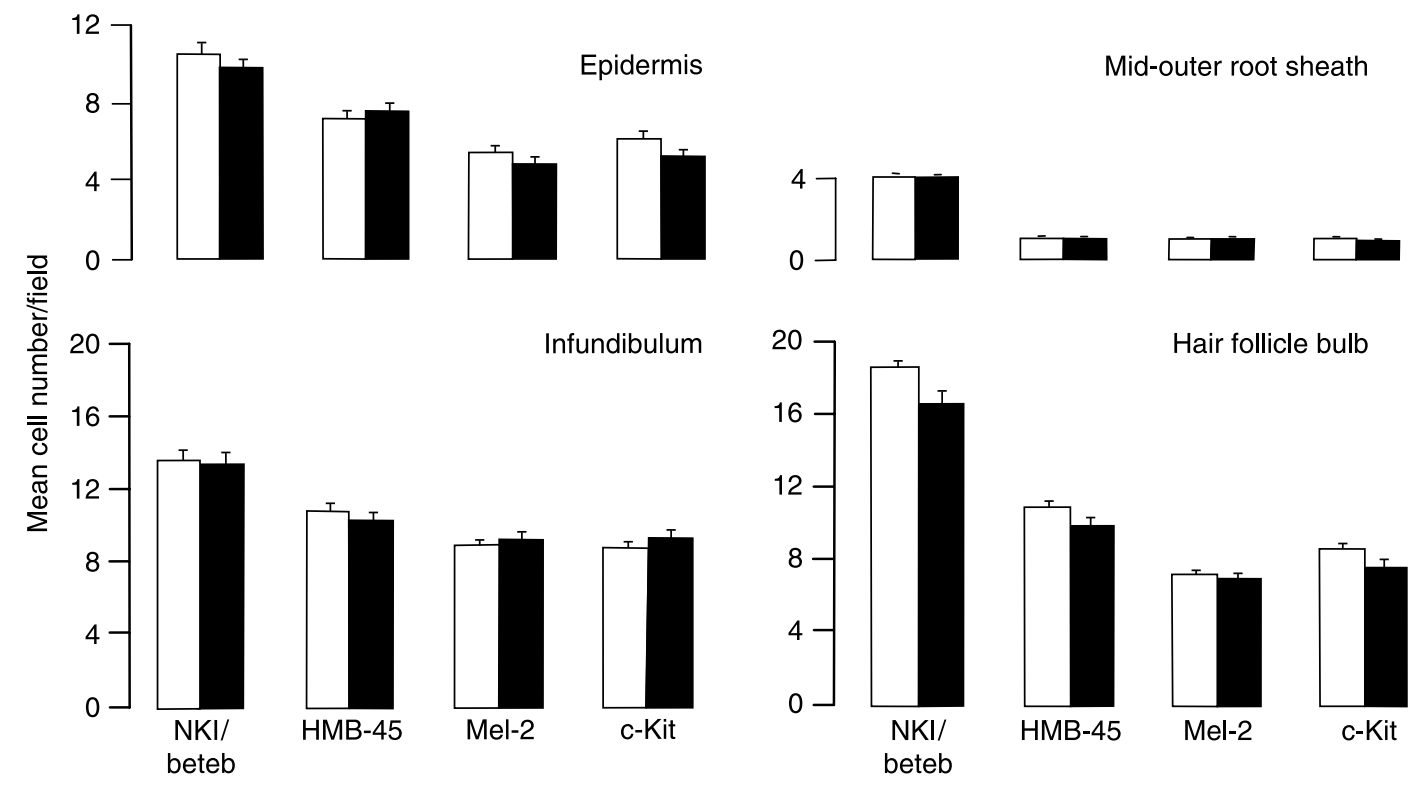

Figure 1 Comparison of the numbers of cells stained by antibodies to three melanocyte markers and c-Kit in the epidermis and hair follicle of normal and androgenetic alopecia scalp. Results are the mean \pm s.E.M. values from eight non-balding (black bars) and eight balding (grey bars) individuals of the number of cells stained with each antibody per field at high magnification. Although there were marked differences between the concentrations of cells in each area of the follicle, there were no differences in staining between normal and androgenetic alopecia individuals in any area, including the hair bulb, with any antibody. 

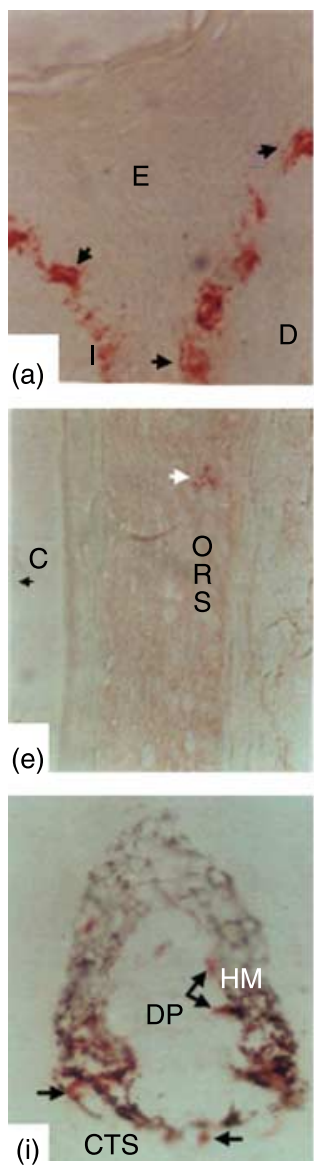
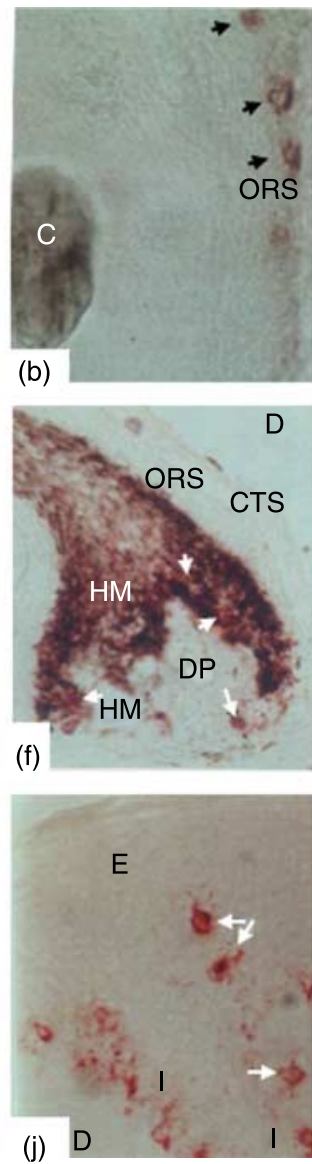
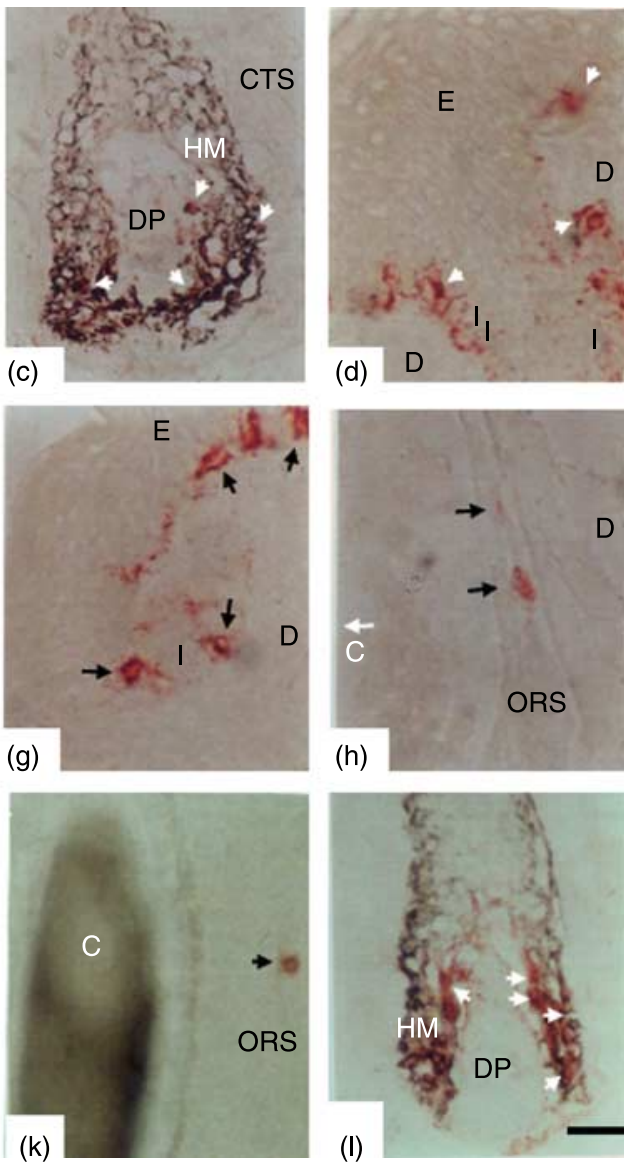

Figure 2 Antibodies to three melanocyte-lineage antigens plus c-Kit (the receptor for SCF) stained variable numbers of cells in the basal layer of scalp epidermis, the outer layer of the outer root sheath of the infundibulum and mid-follicle and the matrix of the hair bulb. (a-c) NKI/beteb (Mag.); (d-f) HMB-45; (g-i) Mel-2 (Mag.); (j-l) c-Kit. Positive staining is red and melanin pigment is brown. $(\mathrm{a}, \mathrm{d}, \mathrm{g}, \mathrm{j})$ show staining in the epidermis (E) and infundibulum (I) but not in the dermis (D); (b, e, h and $k$ ) in the outer root sheath of the permanent middle part of the follicle below the sebaceous gland, hair cortex (C); (c, f, i and I) show red cellular staining plus brown melanin in the matrix of the hair bulb (HM) above and around the dermal papilla (DP). Occasional staining can be seen at the bottom of the bulb away from the pigmented regions (e.g. f). Some staining in each figure is highlighted by arrow. CTS indicates connective tissue, or dermal, sheath. Scale bar represents $100 \mu \mathrm{m}$ in $\mathrm{c}, \mathrm{e}, \mathrm{f}, \mathrm{h}, \mathrm{i}, \mathrm{k}, \mathrm{I}$ and $62 \cdot 5 \mu \mathrm{m}$ in $\mathrm{a}, \mathrm{b}, \mathrm{d}, \mathrm{g}, \mathrm{j}$.

significantly lower than those by NKI/beteb (epidermis, $6 \cdot 80 \pm 0 \cdot 25, P<0 \cdot 01$; infundibulum, $9 \cdot 50 \pm 0 \cdot 50, P<0 \cdot 01$; mid-follicle, $1: 00 \pm 0 \cdot 7, P<0 \cdot 001$; hair bulb, $9 \cdot 00 \pm 0 \cdot 42$, $P<0 \cdot 01$; Fig. 1).

\section{Colocalisation analysis of melanocyte-lineage cells in scalp skin}

Dual labelling studies showed that cells in all areas exhibiting single antibody staining coexpressed HMB-45, Mel-5 and c-Kit with NKI/beteb. The cells staining only with $\mathrm{NKI} /$ beteb were also seen in limited numbers in the epidermis (Fig. 2a and b), infundibulum (Fig. 2c) and hair bulb (Fig. 2e), but were the majority amongst the fewer cells in the mid-follicle ORS (Fig. 2d); there was no evidence of staining with c-Kit antibody in many of these cells (Fig. 3A). The antibody to c-Kit also marked cells in the dermis outside the follicle, which were not recognised by NKI/beteb, presumably mast cells (see 2c, d \& e; Costa et al. 1996).

\section{Cultured melanocytes}

Epidermal melanocyte cultures showed an increase in the number of differentiated dendritic cells that formed more pigment with time in culture. Parallel hair follicle melanocyte cultures contained two distinct populations: actively dividing bipolar, non-pigmenting melanocytes termed hair follicle melanocyte I or HFM-I by Tobin et al. (1995) and highly 
A (a)

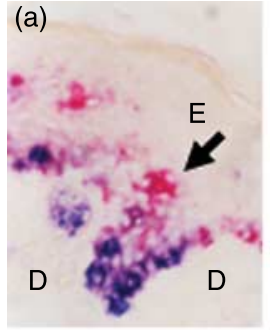

(b)

(c)

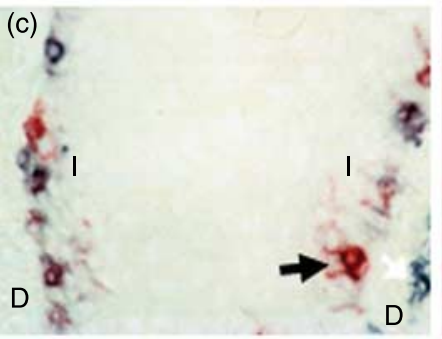

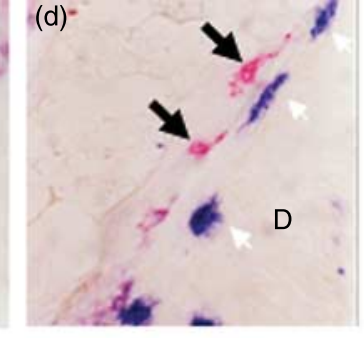

(17)

HM
E

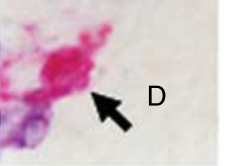

DP

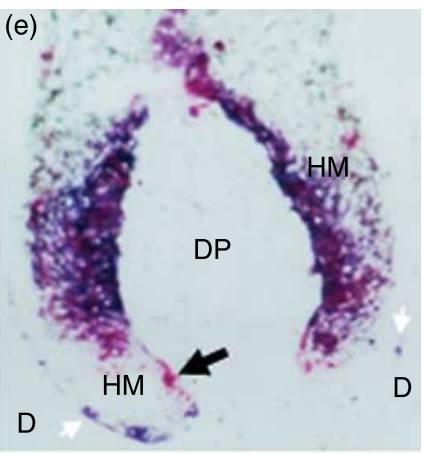

Scale bar

NKI/beteb alone

c-Kit alone

$\mathrm{NK} / /$ beteb + c-Kit

B
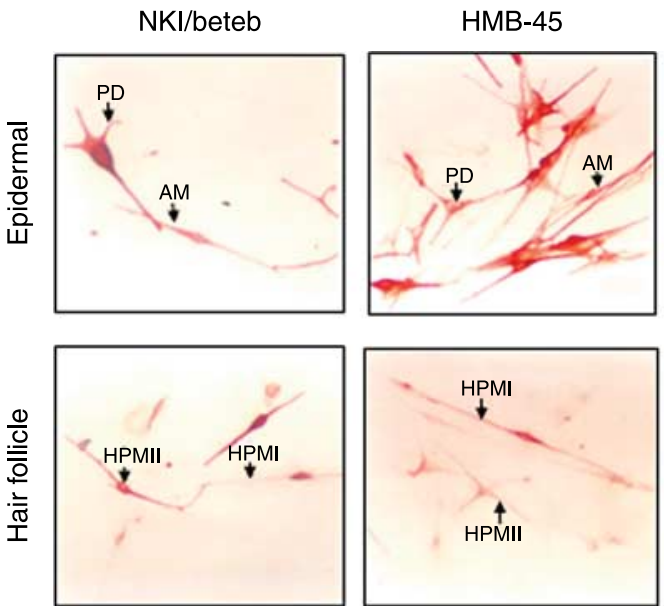

HMB-45
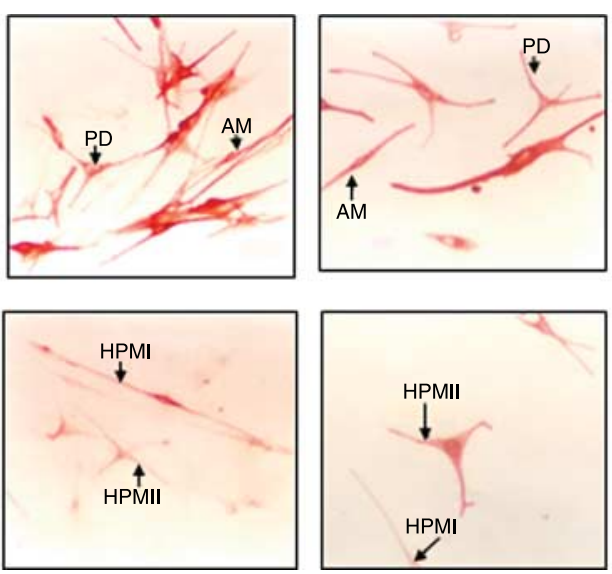
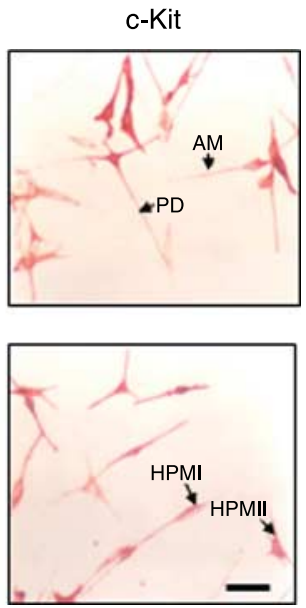

Figure 3 (A) Colocalisation of c-Kit with melanocyte antigen NKI/beteb. Colocalisation studies confirmed that cells expressing NKI/beteb also simultaneously exhibited c-Kit in the epidermis (E), infundibulum (I), ORS and hair bulb. Some cells in all areas, and the majority in the mid-follicle ORS (d), also exhibited only $\mathrm{NKI} /$ beteb staining confirming at least two types of melanocyte-lineage cells in the follicle. Bar represents: (a) epidermis $(62.5 \mu \mathrm{m})$; (b) epidermis at greater magnification $(25 \mu \mathrm{m})$; (c) infundibulum $(62.5 \mu \mathrm{m})$; (d) midfollicle ORS $(62.5 \mu \mathrm{m})$; (e) hair bulb $(100 \mu \mathrm{m})$; and (f) hair bulb at higher magnification $(25 \mu \mathrm{m})$. Red or blue cells show single staining, dual stained cells are purple. Red stain indicates $\mathrm{NKI} /$ beteb and blue indicates c-Kit. Brown/black in hair bulb is melanin pigment. Black arrows highlight NKI/beteb-only stained cells. Blue stained cells outside the hair follicle like those marked by white arrowheads (e.g. c, $d$ and e) are not of melanocyte-lineage and are probably mast cells (D, dermis; DP, dermal papilla; E, epidermis; HM, Hair matrix (site of keratinocyte division and initial differentiation) in hair bulb; I, infundibulum). (B) Cultured hair follicle and epidermal melanocytes exhibit three melanocyte-lineage antigens and c-Kit. Melanocytes (passage 2) derived from scalp epidermis and hair follicles of the same individual exhibit staining for melanocyte antigens NKI/beteb, HMB-45 and Mel-2 and c-Kit by immunocytochemistry. Views were selected to show pigmenting (PD) and less pigmented, amelanotic (AM) epidermal melanocytes and both actively dividing bipolar melanocytes (HFM-I) and highly pigmented, differentiated cells (HFM-II). Epidermal melanocytes, upper row, hair follicular melanocytes, lower row. Scale bar represents $150 \mu \mathrm{m}$.

pigmented, differentiated cells that were lost by passage 3, HFM-II. Cultured epidermal and hair follicle melanocytes derived from the same individuals exhibited staining with antibodies for all three melanocyte-lineage antigens, plus c-Kit (Fig. 3B); no staining occurred with the negative control antibody with either cell type. Although staining in follicular melanocytes varied with some cells staining heavily and others to a lesser extent, there was no consistent difference between the two populations and bipolar melanocytes exhibited both patterns. 


\section{Androgenetic alopecia scalp skin}

The distribution and pattern of the staining of each antibody in the epidermis, infundibulum, hair follicle and hair bulb were the same in balding scalp skin samples as in non-balding scalp. Quantitation and statistical analysis confirmed the same significant differences in distribution between NKI/beteb and the other two melanocyte markers, HMB-45 and Mel-2 plus c-Kit as seen in normal scalp, in all sites examined (Fig. 1). There were no significant differences between the numbers of cells per unit area in balding or non-balding scalp (Fig. 1), when the results were compared for each antibody in each region.

\section{Reduction in SCF production by balding dermal papilla cells}

Androgenetic alopecia dermal papillae were more difficult to isolate, due to the smaller size of the follicles, and to establish the cell cultures from normal scalp, as reported previously (Randall et al. 1996). The ELISA for SCF proved very reproducible with very little variation between duplicates or between different plates; serial dilution of pure SCF produced linear graphs when plotted against absorbance. Neither control serum-free medium nor media conditioned for $15 \mathrm{~min}$ by dermal papilla cells from either non-balding or balding scalp hair follicles contained detectable SCF. However, media conditioned for $24 \mathrm{~h}$ by all individual primary cell lines of scalp dermal papilla cells contained SCF (Fig. 4). Dermal papilla cells derived from androgenetic alopecia scalp follicles secreted significantly less SCF $(2 \cdot 25 \pm 0 \cdot 26 \mu \mathrm{g} / \mathrm{mg}$ protein) than those from non-balding scalp (3.09 $\pm 0.38 ; P<0 \cdot 05)$. Adding $10 \mathrm{nM}$ testosterone in vitro had no effect on the amount produced by balding scalp cell lines at either time point (Fig. 4).

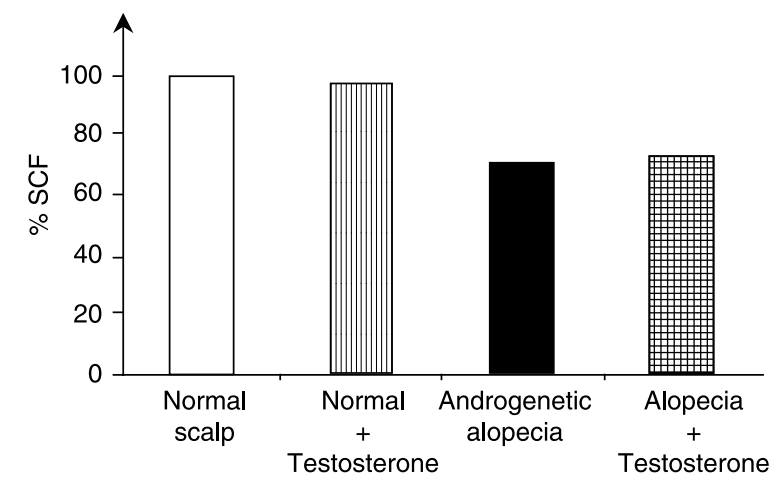

Figure 4 Dermal papilla cells from androgenetic alopecia follicles secrete less SCF in culture than those from non-balding scalp cells. The levels of SCF in serum-free medium conditioned for $24 \mathrm{~h}$ by non-balding (vertical shading) and balding scalp (horizontal shading) dermal papilla cells in the presence (darker shading), or absence (light shading), of $10 \mathrm{nM}$ testosterone were measured by ELISA. An initial collection of 15-minute conditioned media contained no detectable SCF (data not shown). Results are the means of seven non-balding and five balding primary cell lines expressed as a percentage of the values for non-balding cells cultured in the absence of testosterone.

\section{Discussion}

Expression of c-Kit by melanocyte-lineage cells in human hair follicles

The cells exhibiting three melanocyte-lineage antigens, plus c-Kit, the SCF receptor, were located by immunohistochemistry in four main areas of normal and androgenetic alopecia scalp: the epidermal basal layer; the follicle infundibulum; the mid-follicle ORS; and the hair bulb. These antigens were also expressed by cultured human epidermal and hair follicle melanocytes. This concurs with earlier studies of human epidermis (Grichknik et al. 1996, 1998, Norris et al. 1996) and rodent hair follicles (Okura et al. 1995, Botchkareva et al. 2001), and with $\mathrm{NKI} /$ beteb distribution in human follicles (Horikawa et al. 1996, Commo \& Bernard 2000) and cultured melanocytes (Tobin \& Bystryn 1996, Zhu et al. 2004, Ma et al. 2006).

There were slightly more stained cells in the infundibulum, than the epidermis (concurring with Grichnik et al. (1996)), and the hair bulb (Fig. 1). In the bulb, all antibodies stained cells amongst the matrix pigment around the upper dermal papilla (Fig. 2), the classical follicle pigment unit (Slominski et al. 2004); occasional, more rounded cells at the matrix edges, mostly slightly lower than the dermal papilla base, also expressed all antigens (e.g. Figure $2 \mathrm{f}$ and i). In the mid-follicle ORS small, oval cells were detected in much lower concentrations than elsewhere $(P<0 \cdot 001$; Figs $1-3 \mathrm{~A})$. The strong correlation in cell numbers detected by HMB-45 and Mel-2 (Fig. 1) and their staining of cultured melanocytes (Fig. 4) suggests that these antibodies recognised the same well-developed melanocytes (Adema et al. 1993, Horikawa et al. 1996), supporting the quantitation's validity. Interestingly, similar cell numbers also exhibited c-Kit in each area (Fig. 1); scalp epidermal melanocyte expression concurs with forearm (Norris et al. 1996) and foreskin studies (Grichnik et al. 1996). Melanocyte c-Kit expression was confirmed by staining in cultured epidermal and hair follicle melanocytes (Fig. 3B) and colocalisation with NKI/beteb (Fig. 3A). Thus, differentiated melanocytes in all sites can respond to SCF.

In marked contrast, $\mathrm{NKI}$ /beteb detected significantly more cells in every region (Fig. 1) as previously reported in the human epidermis (Grichnik et al. 1996) and the ORS (Horikawa et al. 1996, Commo et al. 2004b). Since NKI/ beteb stains antigens in premelanosome-like structures as well as premelanosomes and melanosomes (Hayashibe et al. 1986), it is presumably recognising very early melanocyte-lineage cells in addition to the more differentiated melanocytes detected by the other antibodies (Adema et al. 1993, Horikawa et al. 1996). The greater number of cells expressing NKI/beteb than c-Kit, (Fig. 1), confirmed by colocalisation studies (Fig. 3A), indicates small numbers of much less differentiated SCF/c-Kit independent melanocyte-lineage cells in each area. A small percentage of less differentiated stem cells would be predicted within any renewing tissue like the follicle or epidermis. Since epidermal repigmentation 
spreads out from hair follicles in treated vitiligo (Ortonne et al. 1979, Cui et al. 1991, Na et al. 1998) or after dermabrasion (Staricco 1960, 1961), undifferentiated infundibular cells could be moving from the mid-follicle or a local reserve of stem cells. In the hair bulb, the difference between NKI/beteb and other antigens' expression was greater $(2 \cdot 2: 1)$ than in the infundibulum or epidermis $(1 \cdot 6: 1)$ and some cells only expressed NKI/beteb during dual staining (Fig. 3e and f). These could be a stem cell reservoir for the bulb, to enable melanin production to continue throughout the very long anagen of human scalp hair; less differentiated melanocytes were detected in the lower bulb rim after dermabrasion (Staricco 1960). Since melanin synthesis produces damaging oxidative stress (Arck et al. 2006) replacement melanocytes may be necessary to maintain the pigment. Such less differentiated cells could also be the few melanocytes that persist after anagen, moving upwards in catagen to the telogen capsule and possibly populating the next anagen bulb (Commo \& Bernard 2000, Sharov et al. 2005). The local signals that stimulate their maturation to pigment-producing melanocytes or migration would not involve SCF as they do not express c-Kit.

In human follicles, the mid-follicle ORS is believed to mirror the rodent follicle bulge as the stem cell niche for melanocyte-lineage cells (Staricco 1959, Sugiyama \& Kukita 1976, Horikawa et al. 1996, Narisawa et al. 1997, Commo \& Bernard 2000, Botchkareva et al. 2001, Nishimura et al. 2002, 2005, Steingrimsson et al. 2005). Follicular epithelial stem cells also reside in the bulge/permanent ORS (Costarelis et al. 1990, Lyle et al. 1998, Waters et al. 2007). Our mid-follicle ORS results confirm this stem cell niche as four times more cells were detected with $\mathrm{NKI}$ /beteb than the other markers, unlike the lower ratios elsewhere (Fig. 1), confirmed by colocalisation studies. These results support earlier observations of amelanocytic melanocytes (Staricco 1959, 1960, 1961, Staricco \& Miller-Milinska 1962) and NKI/beteb expression (Horikawa et al. 1996, Narisawa et al. 1997, Commo \& Bernard 2000) in human ORS; they indicate two types of melanocyte-lineage cells: immature cells expressing only NKI/beteb, often seen in groups, presumably stem cells; and small numbers of more differentiated cells expressing melanocyte and c-Kit antigens, probably the next stage of differentiation. This agrees with observations of melanin (Narisawa et al. 1997) and both rounded and dendritic cells (Commo \& Bernard 2000) in the ORS. No c-Kit expression by most mid-follicle ORS melanocytes concurs with its absence from mice bulge melanocytes (Botchkareva et al. 2001) and the c-Kit-independence of mouse melanocyte stem cells (Nishimura et al. 2002). The undifferentiated human ORS melanocytes seen here presumably give rise to transient amplifying cells that express c-Kit and migrate under SCF control as in the mouse (Nishimura et al. 2002).

Melanin was normally only visible in the hairs and hair bulbs indicating that only matrix melanocytes were producing melanin. Occasional balding epidermis pigment was presumably stimulated by greater exposure to sunlight with reduced hair cover. These dramatic differences in pigment, despite similar concentrations of differentiated melanocytes in the bulb, epidermis and infundibulum, indicate major variations in melanin-producing activity, presumably due to regional differences in the local regulators. Epidermal pigmentation increases locally in response to u.v. light with greater local production of paracrine regulators, including SCF (Hachiya et al. 2001, Slominski et al. 2004). The SCF/ c-Kit pathway is definitely functional in adult epidermal pigmentation; SCF activates melanocytes in vivo (Grichnik et al. 1998, Costa et al. 1996) and in xenografts (Grichnik et al. 1998, Sriwiriyanont et al. 2006), while c-Kit antibodies inhibit xenograft melanocytes. Since c-Kit antibodies prevent hair pigmentation in adult mice follicles (Botchkareva et al. 2001), c-Kit expression by human follicular melanocytes strongly indicates a role for SCF/c-Kit signalling in human follicular pigmentation. Further support comes from reversible hair greying in cancer patients whose tyrosine kinase interfering chemotherapy (Moss et al. 2003, Routhouska et al. 2006) presumably blocks post-receptor c-Kit signalling, as $\mathrm{c}-\mathrm{Kit}$ is a tyrosine kinase receptor.

\section{Androgenetic alopecia}

There were no differences between normal and balding scalp in staining patterns or cell concentrations with any antibody in the hair bulb or elsewhere (Fig. 1). Therefore, neither lower bulb melanocyte concentration nor c-Kit expression is responsible for reduced pigmentation during androgenetic alopecia miniaturisation. Although post-receptor signalling defects are possible, this would reduce melanocytes entering the bulb, like mouse anti-c-Kit antibody treatment (Botchkareva et al. 2001). A decrease in the local regulators seems more likely. The dermal papilla is a strong candidate to supply local pigment regulators as it determines what hair type is produced (Reynolds \& Jahoda 2004), is the focus for the follicle pigment unit (Slominski et al. 2004) and the centre of androgen action (Randall 2007). This would enable a mechanism for circulating hormones to alter hair colour in tandem with environmental or developmental changes by altering dermal papilla production of SCF and/or other regulators.

Cultured dermal papilla cells from intermediate androgenetic alopecia follicles secreted about two-thirds less SCF than non-balding cells (Fig. 4). There is substantial evidence that cultured dermal papilla cell behaviour reflects that of the in vivo dermal papilla. Cultured human and rat dermal papilla cells induce new follicle formation when re-implanted in vivo (Reynolds \& Jahoda 2004) and human cells derived from follicles with different androgen responses in vivo retain appropriate different characteristics in vitro (Randall et al. 2003) indicating androgen exposure in vivo established their gene expression. These include biologically relevant androgen receptor and $5 \alpha$-reductase gene expression in androgen-responsive dermal papilla cells (Ando et al. 1999). Cultured beard and androgenetic alopecia cells also exhibit 
specific, high-affinity, low-capacity hormone binding, i.e. androgen receptors (Randall et al.1992, Hibberts et al. 1998). Particularly importantly, cultured dermal papilla cell capacity to metabolise testosterone to the more potent $5 \alpha$-dihydrotestosterone reflects hair growth in $5 \alpha$-reductase deficiency with beard, but not pubic, axillary nor non-balding scalp, cells forming $5 \alpha$-dihydrotestosterone (Itami et al. 1990, Thornton et al. 1993, Hamada et al. 1996). Additionally, only androgenresponsive cells alter their protein production in response to androgen with effects reflecting their androgen responses in vivo (Itami et al. 1995, Hibberts \& Randall 1996, Obana et al. 1997, Thornton et al. 1998, Sonada et al. 1999, Inui et al. 2002, Hibino \& Nishiyama 2004). The reduced SCF production by balding dermal papilla cells (Fig. 4) parallels other differences between balding and non-balding scalp dermal papilla cells. Androgenetic alopecia cells contain higher levels of androgen receptors than non-balding cells (Hibberts et al. 1998), secrete less growth-promoting factors, produce inhibitory factors that delay rodent hair growth in vivo (Hamada \& Randall 2006) and respond appropriately to testosterone in vitro (Hibberts \& Randall 1996, Sonada et al. 1999, Inui et al. 2002, Hibino \& Nishiyama 2004).

In vitro testosterone had no effect on the SCF amounts secreted by balding cells. Although drawing inferences from absent in vitro responses are difficult as conditions may not fully recapitulate in vivo, androgenetic alopecia cells contain androgen receptors (Hibberts et al. 1998) and respond to androgens in vitro by decreasing their growth-stimulatory capacity (Hibberts \& Randall 1996) and altering their production of TGF- $\beta$ (Hibino \& Nishiyama 2004) and protease nexin-1 (Sonada et al. 1999) indicating functional receptor-mediated responses. There was also no alteration in beard dermal papilla cell SCF production with testosterone (Hibberts et al. 1996), although testosterone in vitro increased beard cell production of mitogenic factors (Thornton et al. 1998) and IGF-1 (Itami et al. 1995). Beard cells secreted much more SCF, about $250 \%$ of normal scalp, and more than $3.5 \times$ these balding cell levels; beard hairs are normally the darkest hairs. This suggests that androgens alter dermal papilla cell $s f$ gene expression either prior to, or during, the early stages of anagen thereby setting that cycle's pigment level. This seems likely as hair colour is normally relatively constant along a hair, even during several years of growth. These changes in scf gene expression are alterable during future hair cycles; treatment with $5 \alpha$-reductase inhibitors stimulates regrowth of large, pigmented terminal hairs (Kaufman et al. 1998, Olsen et al. 2006) and antiandrogens reduce hair colour in hirsutism (Sawers et al. 1982). However, antiandrogens do not alter the colour or size of hair in hirsutism quickly, unlike their effect on the sebaceous glands; follicles with long cycles such as the beard also take longer to respond than those with shorter cycles on the thigh (Sawers et al. 1982). This supports the concept of androgens acting prior to, or at the beginning of the next anagen rather than affecting follicles during mid-anagen.

In summary, these experiments highlight three types of melanocyte in human scalp anagen hair follicles (Table 1). First, the classic hair bulb melanocyte expressing all melanocyte markers and $\mathrm{c}$-Kit and actively producing melanin, presumably in response to the dermal papilla's SCF. Secondly, melanocytes expressing these antigens, but not making melanin, apparently differentiated cells ready for signals to produce pigment or migrate; these were found in similar numbers in the infundibulum and epidermis, but far fewer in the bulb and mid-follicle ORS. Thirdly, less differentiated cells, only expressing NKI/beteb, probably forms of melanocyte stem cell, were present in small numbers in all areas and were the majority in mid-follicle ORS. During follicular melanocyte culture two types were observed here and elsewhere (Hu et al. 1957, Tobin \& Bystryn, 1996, Ma et al. 2006, Na et al. 2006), including less differentiated, bipolar forms with great dividing capacity. These SCF/c-Kitindependent cells in the mid-follicle ORS, the follicle stem cell niche, correspond to c-Kit-negative stem cells in mice (Nishimura et al. 2002, Steingrimsson et al. 2005). Similar undifferentiated cells in the bulb may be a reservoir to maintain pigmentation through long scalp anagens and/or melanocytes, which survive catagen and repopulate the next bulb (Commo \& Bernard 2000, Sharov et al. 2005).

What signals activate the c-Kit-independent, immature cells in the bulb or ORS melanocyte stem cell niche is unknown; other melanocyte modulators such as endothelin 1 and 3 , hepatocyte growth factor and basic fibroblast growth factor are possibilities (reviewed Lin \& Fisher 2007). Identifying these could facilitate development of useful

Table 1 Summary of pigment formation and distribution of melanocyte-lineage cells in human scalp epidermis and hair follicles. Results of immunohistochemical analysis of human scalp skin with antibodies, NKI/beteb, which recognise all melanocyte-lineage cells, HMB-45 and Mel-2, which recognise differentiated melanocytes, and to c-Kit, the receptor for stem cell factor

\begin{tabular}{|c|c|c|c|}
\hline & Pigment & NKI/beteb & NKI/beteb, HMB-45, Mel-2, c-Kit \\
\hline $\begin{array}{l}\text { Epidermis } \\
\text { Infundibulum } \\
\text { Mid-follicle ORS } \\
\text { Hair bulb }\end{array}$ & ++++++ & $\begin{array}{l}+++ \\
++++ \\
++++ \\
+++++\end{array}$ & $\begin{array}{l}++++++++ \\
++++++++++ \\
+ \\
++++++++++\end{array}$ \\
\hline
\end{tabular}

Presence is indicated by + , with more + indicating greater numbers of cells or pigment, + ? indicates epidermal pigment in normal caucasian scalp is usually very limited. 
clinical treatments; increasing hair pigmentation in androgenetic alopecia would increase hair visibility even without hair enlargement, and inhibition would reduce it in hirsutism. Such therapies may also reduce canites, age-related greying.

There were no differences in distribution, expression pattern or cell concentration between normal and androgenetic alopecia follicles, but cultured dermal papilla cells from androgenetic alopecia follicles secreted less SCF. This suggests that the mechanism for reduced hair pigment in androgenetic alopecia involves androgens binding to androgen receptors in the dermal papilla, probably at the beginning of anagen, inhibiting SCF gene expression and synthesis by dermal papilla cells throughout anagen causing bulb melanocytes to produce less pigment. Although normal and androgenetic alopecia follicles contained the same concentration of melanocytes, the follicles were smaller and the total number of bulb melanocytes reduced. Since SCF is implicated in the movement of melanocyte-lineage cells into developing follicles and adult mouse bulbs (Jordan \& Jackson 2000, Botchkareva et al. 2001), this would be expected if less SCF was produced by balding dermal papillae during hair bulb reformation in early anagen. Overall, these observations suggest that modifiers of SCF/c-Kit signalling, or the unidentified regulators of the c-Kit-negative melanocyte stem cells, could offer future routes to alter hair pigmentation for clinical effect in androgen-modulated hair disorders including hirsutism and androgenetic alopecia or cosmetically for greying.

\section{Acknowledgements}

The authors are grateful for helpful guidance with melanocyte culture from Prof Desmond Tobin and for beneficial discussions with Prof John Wood, both at the School of Life Sciences, University of Bradford. They also gratefully acknowledge a fellowship from CAPES, Brazil to support I $\mathrm{O}$ de $\mathrm{O}$ and a research studentship from the University of Bradford for TJJ. The authors have no conflict of interest that would prejudice the impartiability of this paper.

\section{References}

Adema GJ, de Boer AJ, Van't Hullernaar R, Denijn M, Ruiter DJ, Vogel AM \& Figdor CG 1993 Melanocyte-lineage specific antigens recognized by monoclonal antibodies NKI/beteb, HMB-50 and HMB-45 are encoded by a single cDNA. American Journal of Pathology 143 1579-1585.

Ando Y, Yamaguchi Y, Hamada K, Yoshikawa K \& Itami S 1999 Expression of mRNA for androgen receptor, $5 \alpha$-reductase and $17 \beta$-hydroxysteroid dehydrogenase in human dermal papilla cells. British Journal of Dermatology $141840-845$.

Arck PC, Overall R, Spatz K, Liezman C, Handjiski B, Klapp BF, BirchMachin MA \& Peters EMJ 2006 Towards a 'free radical theory of graying': melanocyte apoptosis in the aging human hair follicle is an indicator of oxidative stress induced tissue damage. FASEB Journal 20 E908-E920.

Bhawan J 1997 Mel-5: a novel antibody for differential diagnosis of epidermal pigmented lesions of the skin in paraffin-embedded sections. Melanoma Research 7 43-46.
Botchkareva NV, Khlgatian M, Longley BJ, Botchkarev VA \& Gilchrest BA $2001 \mathrm{SCF} / \mathrm{c}-\mathrm{Kit}$ signaling is required for cyclic regeneration of the hair pigmentation unit. FASEB Journal 15 645-658.

Bradford MM 1976 A rapid and sensitive method for the quantification of microgram quantities of protein utilising the principle of protein dye binding. Analytical Biochemistry 72 248-254.

Bubenik GA \& Bubenik AB 1985 Seasonal variations in hair pigmentation of white-tailed deer and their relationship to sexual activity and plasma testosterone. Journal of Experimental Zoology 235 387-395.

Burnett JB, Holstein TJ \& Quevedo WC 1969 Electrophoretic variations of tyrosinase in follicular melanocytes during the hair growth cycle in mice. Journal of Experimental Zoology 171 369-376.

Castanet J \& Ortonne J-P 2000 Hair pigmentation. In Hair and its Disorders: Biology, Pathology and Management, pp 49-65. Eds FM Camacho,

VA Randall \& VH Price. London: Martin Dunitz.

Chase HB 1958 The behaviour of pigment cells and epithelial cells in the hair follicle. In The Biology of Hair Growth, pp 29-237. Eds W Montagna \& RA Ellis. New York: Academic Press.

Commo S \& Bernard BA 2000 Melanocyte subpopulation turnover during human hair cycle: an immunohistochemical study. Pigment Cell Research $\mathbf{1 3}$ 253-259.

Commo S, Gaillard O \& Bernard BA 2004a Absence of TRP-2 in melanogenic melanocytes of human hair. Pigment Cell Research 17 488-497.

Commo S, Gaillard O \& Bernard BA 2004b Human hair greying is linked to a specific depletion of hair follicle melanocytes affecting both the bulb and the outer root sheath. British Journal of Dermatology 150 435-443.

Costa JJ, Demetri GD \& Harrist TJ 1996 Recombinant human stem cell factor (kit ligand) promotes human mast cell and melanocyte hyperplasia and functional activation in vivo. Journal of Experimental Medicine $\mathbf{1 8 3}$ 2681-2686.

Costarelis G, Sun T-T \& Lavker RM 1990 Label-retaining cells reside in the bulge area of pilosebaceous unit: implications for follicular stem cells, hair cycle and skin carcinogenesis. Cell 61 1329-1337.

Costin GE \& Hearing VJ 2007 Human skin pigmentation: melanocytes modulate skin colour in response to stress. FASEB Journal 21 976-994.

Cui J, Shen LY \& Wang GC 1991 Role of hair follicles in the repigmentation of vitiligo. Journal of Investigative Dermatology 97 410-416.

Eisinger M \& Marko O 1982 Selective proliferation of normal human melanocytes in vitro in the presence of phorbol ester and cholera toxin. PNAS 79 2018-2022.

Fleischman RA, Saltman DL, Stastry V \& Zneimer S 1991 Deletion of the c-Kit proto-oncogene in the human developmental defect piebald trait. PNAS 88 10885-10889.

Flux JEC 1970 Colour change of mountain hares (Lepus timidus scotius) in north-east Scotland. Journal of Zoology 162 345-358.

Geissler EN, Cheng SV, Gusella JF \& Housmann D 1988 The dominantwhite spotting $(\mathrm{W})$ locus of the mouse encodes the $c$-kit proto-oncogene. Cell 55 185-192.

Grichnik JM, Wazir NA, Burch JA, Byers JD, Garcia CA, Clark E \& Shea CR 1996 KIT expression reveals a population of precursor melanocytes in human skin. Journal of Investigative Dermatology 106 967-971.

Grichnik JM, Burch JA, Burchette J \& Shea CR 1998 The SCF/KIT pathway plays a critical role in the control of normal human melanocyte homeostasis. Journal of Investigative Dermatology 111 233-238.

Haase E, Ito S \& Wakanatsu K 1995 Influences of sex, castration and androgens on the eumelanin and pheomelanin contents of different feathers in wild mallards. Pigment Cell Research 8 164-170.

Hachiya A, Kobayashi A, Ohuchi A, Takema Y \& Imokawa G 2001 The paracrine role of stem cell factor/c-kit signaling in the activation of human melanocytes in ultraviolet-b-induced pigmentation. Journal of Investigative Dermatology 116 578-586.

Halaban R \& Alfano FD 1984 Selective elimination of fibroblasts from cultures of normal human melanocytes. In Vitro 20 447-450.

Hamada K \& Randall VA 2006 Inhibitory autocrine factors produced by the mesenchyme-derived hair follicle dermal papilla may be a key to male pattern baldness. British Journal of Dermatology 54 609-618. 
Hamada K, Thornton MJ, Laing I, Messenger AG \& Randall VA 1996 The metabolism of testosterone by dermal papilla cells cultured from human pubic and axillary hair follicles concurs with hair growth in $5 \alpha$-reductase deficiency. Journal of Investigative Dermatology 106 1017-1022.

Hamilton JB 1951 Patterned loss of hair in man; types and incidence. Annals of the New York Academy of Sciences $\mathbf{5 3}$ 708-728.

Hamilton JB 1958 Age, sex and genetic factors in the regulation of hair growth in man: a comparison of Caucasian and Japanese populations. In The Biolog $y$ of Hair Growth, pp 399-433. Eds W Montagna \& RA Ellis. New York: Academic Press.

Hayashibe K, Mishima Y, Ichihashi M \& Kawai M 1986 Melanosomal antigenic expression on the cell surface and intracellular subunits within melanogenic compartments of pigment cells: analysis by antimelanosomeassociated monoclonal antibody. Journal of Investigative Dermatology 87 89-94.

Hibberts NA \& Randall VA 1996 Testosterone inhibits the capacity of cultured cells from human balding scalp dermal papilla cells to produce keratinocyte mitogenic factors. In Degroot L J, Jameson J L, editors, Endocrinology 5th Ed Section XIV Burger H G, editor. Male Reproduction, Philadelphia: W B Saunders Co. 303-306.

Hibberts NA, Messenger AG \& Randall VA 1996 Dermal papilla cells derived from beard hair follicles secrete more stem cell factor (SCF) in culture than scalp cells or dermal fibroblasts. Biochemical and Biophysical Research Communications 222 401-405.

Hibberts NA, Howell AE \& Randall VA 1998 Dermal papilla cells from human balding scalp hair follicles contain higher levels of androgen receptors than those from non-balding scalp. Journal of Endocrinology 156 $59-65$.

Hibino T \& Nishiyama T 2004 Role of TGF-b2 in the human hair cycle. Journal of Dermatology Science 35 9-18.

Horikawa T, Norris DA, Johnson TW, Zekman T, Dunscomb N, Bennion SD, Jackson RL \& Morelli JG 1996 Dopa-negative melanocytes in the outer root sheath of human hair follicles express premelanosomal antigens but not a melanosomal antigen or the melanosome-associated glycoproteins, tyrosinase, TRP-1 and TRP-2. Journal of Investigative Dermatology 106 28-35.

Hu F, Staricco RG, Pinkus H \& Forsnaugh RP 1957 Human melanocytes in tissue culture. Journal of Investigature Dermatology 28 15-32.

Inui S, Fukuzato Y, Nakajima F, Yoshikawa K \& Itami S 2002 Androgeninducible TGFbeta1 from balding dermal papilla cells inhibits epithelial cell growth: a clue to understand paradoxical effects of androgen on human hair growth. FASEB Journal 16 1967-1969.

Itami S, Kurata S \& Takayasu S 1990 5-Alpha-reductase activity in cultured human dermal papilla cells from beard compared with reticular dermal fibroblasts. Journal of Investigative Dermatology 94 150-152.

Itami S, Kurata S, Sonada T \& Takayasu S 1995 Interactions between dermal papilla cells and follicular epithelial cells in vitro: effect of androgen. British Journal of Dermatology 132 527-532.

Jansen VAA \& van Baalen M 2006 Altruism through beard chromodynamics. Nature 440 663-666.

Jordan SA \& Jackson IJ 2000 MGF(KIT ligand) is a chemokinetic factor for melanoblast migration into hair follicles. Developmental Biology 225 424-436.

Kapur RP, Bigler SA, Skelly M \& Gown AM 1992 Anti-melanoma monoclonal antibody HMB45 identifies an oncofetal glycoconjugate associated with immature melanosomes. Journal of Histochemistry and Cytochemistry 40 207-212.

Kaufman KD, Olsen EA, Whiting D, Savin R, Devillez R, Bergfeld W, Pricw VH, Van Neste D, Roberts JL, Hordinsky M et al. 1998 Finasteride in the treatment of men with andogenetic alopecia. Journal of the American Academy of Dermatology 39 578-589.

Kligman AG 1959 The human hair cycle. Journal of Investigative Dermatology 33 307-316.

Kunisada T, Yoshida H, Yamazaki H, Miyamoto A, Hemmi H, Nishimura E, Shultz LD, Nishikawa S \& Hayashi S 1998a Transgene expression of steel factor in the basal layer of epidermis promotes survival, proliferation, differentiation and migration of melanocyte precursors. Development 125 2915-2923.
Kunisada T, Lu SZ, Yoshida H, Nishikawa S, Mizoguchi M, Hayashi S, Tyrrell L, Williams DA, Wang X \& Longley BJ 1998 b Murine cutancous mastocytosis and epidermal melanocytosis induced by keratinocyte expression of transgenic stem cell factor. Journal of Experimental Medicine 187 $1565-1573$.

Lin JY \& Fisher DE 2007 Melanocyte biology and skin pigmentation. Nature $445843-850$.

Lü ZF, Cai SQ, Wu JJ \& Zheng M 2006 Biological characterisation of cultured dermal papilla cells and hair follicle regeneration in vitro and in vivo. Chinese Medical Journal 119 275-281.

Lyle S, Christofidou-Solomidou M, Lin Y, Elder DE, Albelda S \& Costarelis G 1998 The C8/144B monoclonal antibody recognizes cytokeratin 15 and defines the location of human hair follicle stem cells. Journal of Cell Science $\mathbf{1 1 1}$ 3179-3188.

Ma H-J, Yue X-Z, Wang D-G, Li C-R \& Zhu W-Y 2006 A modified method for purifying amelanotic melanocytes from human hair follicles. Journal of Dermatology 33 239-248.

Marshall WA \& Tanner JM 1970 Variations in the pattern of pubertal changes in boys. Archives of Disease in Childhood 45 13-23.

Marzia D, Schatten G \& Sale W 1975 Adhesion of cells to surfaces coated with poly-L-lysine. Journal of Cell Biology 66 198-203.

Messenger AG 1984 The culture of dermal papilla cells from human hair follicles. British Journal of Dermatology 110 685-689.

Moss KG, Toner GC, Cherrington JM, Mendel DB \& Laird AD 2003 Hair depigmentation is a biological readout for pharmacological inhibition of kit in mice and humans. Journal of Pharmacology and Experimental Therapeutics 307 476-480.

Na GY, Seo SK \& Choi SK 1998 Single hair grafting for the treatment of vitiligo. Journal of the American Academy of Dermatology 38 580-584.

Na GY, Paek SH, Park BC, Kim DW, Lee WJ, Lee SJ, Kim MK \& Kim JC 2006 Isolation and characterization of outer root sheath melanocytes of human hair follicles. Journal of Dermatology 155 902-909.

Narisawa Y, Kohda H \& Tanaka T 1997 Three-dimensional demonstration of melanocyte distribution of human hair follicles: special reference to the bulge area. Acta Dermato-Venereologica 77 97-101.

Nishikawa S, Kusakabe M, Yoshinaga K, Ogawa M, Hayashi S, Kunisada T, Era T, Sakakur T \& Nishikawa S 1991 In utero manipulation of coat colour formation by a monoclonal anti-c-Kit antibody: two distinct waves of c-Kit-dependancy during melanocyte development. EMBO Journal 10 2111-2118.

Nishimura EK, Jordan S, Oshima H, Yoshida H, Osawa M, Moriyama M, Jackson IJ, Barrandon Y, Miyachi Y \& Nishikawa S 2002 Dominant role of the niche in melanocyte stem-cell fate determination. Nature 416 854-860.

Nishimura EK, Scott RG \& Fisher DE 2005 Mechanisms of hair graying: incomplete melanocyte stem cell maintenance in the niche. Science $\mathbf{3 0 7}$ $720-724$.

Norris A, Todd C, Graham A, Quinn AG \& Thody AJ 1996 The expression of the c-Kit receptor by epidermal melanocytes may be reduced in vitiligo. British Journal of Dermatology 134 299-306.

Obana N, Chang C \& Uno H 1997 Inhibition of hair growth by testosterone in the presence of dermal papilla cells from the frontal bald scalp of the postpubertal stump-tailed macaque. Endocrinology 138 356-361.

Okura M, Maeda H, Nishikawa S \& Mizoguchi M 1995 Effects of monoclonal anti-c-Kit antibody (ACK2) on melanocytes in newborn mice. Journal of Investigative Dermatology 105 322-328.

Olsen EA, Hodinsky M, Whiting D, Stough D, Hobbs S, Ellis ML, Wilson T \& Rittmaster RS, Dutasteride Alopecia Research Team 2006 The importance of dual $5 \alpha$-reductase inhibition in the treatment of male pattern hair loss: results of a randomized placebo-controlled study of dutasteride versus finasteride. Journal of the American Academy of Dermatology $\mathbf{5 5}$ 1014-1023.

Ortonne JP, MacDonald DM, Micoud A \& Thivolet J 1979 PUVA-induced repigmentation of vitiligo: a histochemical (split-DOPA) and ultrastructural study. British Journal of Dermatology 101 1-12.

Randall VA 1994 Androgens and human hair growth. Clinical Endocrinology 40 439-457.

Randall VA 2007 Hormonal regulation of hair follicles exhibits a biological paradox. Seminars in Cell and Developmental Biology 18 274-285. 
Randall VA, Thornton MJ, Hamada K, Redfern CP, Nutbrown M, Ebling FJ \& Messenger AG 1991 Androgens and the hair follicle: cultured human dermal papilla cells as a model system. Annals of the New York Academy of Sciences 642 355-375.

Randall VA, Thornton MJ \& Messenger AG 1992 Cultured dermal papilla cells from androgen-dependant human hair follicles (e.g. beard) contain more androgen receptors than those from non-balding areas of scalp. Journal of Endocrinology 133 141-147.

Randall VA, Hibberts NA \& Hamada K 1996 A comparison of the culture and growth of dermal papilla cells derived from normal and balding (androgenetic alopecia) scalp. British Journal of Dermatology 134 437-444.

Randall VA, Sundberg JP \& Philpott MP 2003 Animal and in vitro models for the study of hair follicles. Journal of Investigative Dermatology. Symposium Proceedings 8 39-45.

Reynolds AJ \& Jahoda CAB 2004 Cultured human and rat tooth papilla cells induce hair follicle regeneration and fiber growth. Differentiation $72566-575$.

Rousseau K, Kauser S, Pritchard LE, Warhurst A, Oliver RL, Slominski A, Wei ET, Thody AJ, Tobin DJ \& White A 2007 Proopiomelanocortin (POMC), the ACTH/melanocortin precursor, is secreted by human epidermal keratinocytes and melanocytes and stimulates melanogenesis. FASEB Journal 21 1844-1856.

Routhouska S, Gilliam AC \& Mirirani P 2006 Hair depigmentation during chemotherapy with a class III/V receptor tyrosine kinase inhibitor. Archives of Dermatology 142 1477-1479.

Sawers RS, Randall VA \& Iqbal MJ 1982 Studies on the clinical and endocrine aspects of antiandrogens. In Hirsutism, pp 145-168. Ed. SL Jeffocate. London: Wiley.

Sharov AA, Tobin DJ, Sharova TY, Atoyan R \& Botchkarev VA 2005 Changes in different melanocyte population during hair follicle involution (catagen). Journal of Investigative Dermatology 125 1259-1267.

Slominski A, Tobin DJ, Shibahara S \& Wortsman J 2004 Melanin pigmentation in mammalian skin and its hormonal regulation. Physiological Reviews 84 1155-1228.

Sonada T, Asada Y, Kurata S \& Takayasu S 1999 The mRNA for protease nexin-1 is expressed in human dermal papilla cells and its level is affected by androgen. Journal of Investigative Dermatology 113 308-313.

Spritz RA, Holmes SA, Itin P \& Kuster W 1992 Novel mutations of the KIT (mast/stem cell growth factor receptor) proto-oncogene in human piebaldism. Journal of Investigative Dermatology 101 22-25.

Sriwiriyanont P, Ohuchi A, Hachiya A, Visscher MO \& Boissy RE 2006 Interaction between stem cell factor and endothelin-1: effects on melanogenesis in human skin xenografts. Laboratory Investigation 86 1115-1125.

Staricco RG 1959 Amelanotic melanocytes in the outer sheath of the human hair follicle-preliminary and short report. Journal of Investigative Dermatology $33295-297$.
Staricco RG 1960 The melanocytes and the hair follicle. Journal of Investigative Dermatology 35 185-194.

Staricco RG 1961 Mechanism of migration of the melanocytes from the hair follicle into the epidermis following dermabrasion. Journal of Investigative Dermatology 36 99-104.

Staricco RG \& Miller-Milinska A 1962 Activation of the amelanotic melanocytes in the outer root sheath of the hair follicle following ultra violet rays exposure. Journal of Investigative Dermatology 39 163-164.

Steingrimsson E, Copeland GC \& Jenkins N 2005 Melanocyte stem cell maintenance and hair graying. Cell 121 9-12.

Sugiyama S \& Kukita A 1976 Melanocyte reservoir in the hair follicles during the hair growth cycle: an electron microscopic study. In Biology and Disease of the Hair, pp 181-200. Ed. K Toda. Baltimore: University Park Press.

Thornton MJ, Laing I, Hamada K, Messenger AG \& Randall VA 1993 Differences in testosterone metabolism by beard and scalp hair follicle dermal papilla cells. Clinical Endocrinology 39 633-639.

Thornton MJ, Hamada K, Messenger AG \& Randall VA 1998 Beard, but not scalp, dermal papilla cells secrete autocrine growth factors in response to testosterone in vitro. Journal of Investigative Dermatology 111 727-732.

Tobin DJ \& Bystryn JC 1996 Different populations of melanocytes are present in hair follicles and epidermis. Pigment Cell Research 9 304-310.

Tobin DJ \& Kauser S 2005 Hair melanocytes as neuro-endocrine sensorspigments for our imagination. Molecular and Cellular Endocrinology 243 1-11.

Tobin D, Colen SR \& Bystryn JC 1995 The isolation and long term culture of human hair follicle melanocytes. Journal of Investigative Dermatology 104 86-89.

Waters JM, Richardson GD \& Jahoda CA 2007 Hair follicle stem cells. Seminars in Cell and Developmental Biology 18 245-254.

West PM \& Packer C 2002 Sexual selection, temperature and the lion's mane. Science 297 1339-1343.

Williams DE, de Vries P, Namen AE, Widmer MB \& Lyman SD 1992 The steel factor. Developmental Biology 151 368-376.

Zhu W, Zhang R, Ma H \& Wang D 2004 Isolation and culture of amelanotic melanocytes from human hair follicles. Pigment Cell Research 17 668-673.

Zsebo KM, Williams DA, Geissler EN, Broudy VC, Martin FH, Atkins HL, Hsu RY, Birkrtt NC, Okino NH, Murdock DC et al. 1990 Stem cell factor is encoded at the $\mathrm{Sl}$ locus of the mouse and is the ligand for the c-Kit tyrosine kinase receptor. Cell 63 213-224.

Received in final form 20 November 2007

Accepted 24 January 2008

Made available online as an Accepted Preprint 24 January 2008 